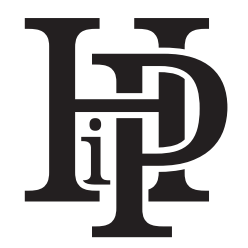

Historia i Polityka

$\operatorname{Nr} 35(42) / 2021$, ss. 127-145

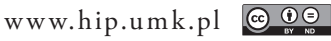

ISSN 1899-5160, e-ISSN 2391-7652

DOI: http://dx.doi.org/10.12775/HiP.2021.008

Marcin ZABORSKI

SWPS Uniwersytet Humanistycznospołeczny, Instytut Nauk Społecznych, Warszawa, Polska

\title{
Droga, brama, szczelina. „Przejście” jako element symboliczny we współczesnych pomnikach i miejscach pamięci
}

\section{Path, Archway, Crevasse: "Gateway" as a Symbol Present in Contemporary Sites of Remembrance}

\section{- Abstrakt •}

Tekst przedstawia zagadnienia związane ze współczesnymi miejscami pamięci. Autor analizuje symbolikę pomników i memoriałów, w których osią upamiętnienia jest „przejście”, brama, szczelina. Pyta o intencje twórców takich miejsc pamięci i podkreśla, że są one nie tylko reprezentacją przeszłości. Zdobywając status symbolu, wyraźnie wpływają na zbiorową wyobraźnię. Nie tylko pielęgnują wspomnienia, ale też odgrywają ważną rolę w budowaniu mostów między przeszłością a teraźniejszością. Wspierają edukację obywatelską i kształtują postawy społeczne.

Słowa kluczowe: pomnik; pamięć zbiorowa; kultura pamięci; Holokaust; Auschwitz

\section{- Abstract •}

The article describes various issues pertaining to the contemporary sites of remembrance. The author analyzes the symbolism of particular kinds of monuments and memorials in the context of an overarching theme of transition or a passage, sometimes represented as a gate or a fissure. The inspiration of creators of such memorials is being theorized by the author. He points out that these memorials are not merely symbols of the past. They constantly influence the collective imagination by gaining a landmark status. Not only do they preserve memories of events and people, but they also function as a bridge between the past and the present. Such sites of remembrance support civic education efforts and have the ability to form societal identity.

Keywords: monument; collective memory; culture of memory; Holocaust; Auschwitz 
Pamięć potrzebuje namacalności rzeczy, ponieważ bez niej zniknęłaby bez śladu. Ta myśl Hanny Arendt kieruje nas w stronę rozmaitych obiektów, które pomagają pielęgnować wspomnienia. To artefakty i relikty stanowiące świadectwo minionych czasów i historycznych wydarzeń. Aleida Assmann przekonywała, że takie postrzeganie ich roli nie rodzi się z fałszywego skupiania się na przedmiotach, ale odnosi się do istoty pamięci, która „inwestuje w przedmioty” i zawdzięcza im swoją charakterystyczną aurę i siłę (Assmann, 2007, s. 12).

Jeśli więc pamięć - także ta obserwowana w wymiarze społecznym - ma być prawdziwa, musi obejmować doświadczenie, interakcje i relacje, które wspierane mogą być za pomocą rozmaitych obiektów. Wykorzystywane w konkretnych koncepcjach komemoratywnych zawierają określoną symbolikę - wpisaną w nie w sposób naturalny lub nadpisaną, to znaczy założoną przez ich twórców. Symbolika ta może być oczywiście odbierana w subiektywny sposób, co sprawia, że odsyła do otwartego zbioru możliwych interpretacji, choć rzecz jasna pewien kierunek myślenia wyznaczają zwykle intencje autorów pomników czy miejsc pamięci (Kącka, 2015, ss. 59-80). Wielu z nich sięga w swych pracach do figury „przejścia”, która wspiera procesy pamięci i pomaga w wywoływaniu określonych reakcji.

Jakie rodzaje tej figury możemy zaobserwować w pomnikowych przestrzeniach? Jakie odgrywają w nich role? Jakie były intencje ich twórców, a jakie wywołują reakcje w odbiorcach? Spróbujmy odpowiedzieć na te pytania, odwołując się do obiektów mieszczących się w tytułowej triadzie - „brama, droga, szczelina” i poddając je analizie - na poziomie założeń przyjmowanych przez ich autorów, jak i późniejszej recepcji tych miejsc. Nie jest tu naszą intencją skatalogowanie ich wszystkich, a jedynie wykorzystanie wybranych przykładów po to, by wskazać pola refleksji i zrozumieć procesy zachodzące w tym obszarze.

\section{Bramy obozów koncentracyjnych}

Obozowe bramy stały się obrazem wręcz ikonicznym. Stanowią wyrazisty symbol terroru i ludobójstwa przywoływany w różnych kontekstach. Zawierają w sobie bogaty ładunek, zarówno informacyjny, jak i emocjonalny. Istotną rolę odgrywają nie tylko w granicach przestrzeni historycznej, do której wprowadzają zwiedzających, ale też daleko poza tymi granicami. W świecie zewnętrznym są - jak nazywa to Tomasz Kranz - „komponentami matrycy narracyjnej, która współkształtuje zbiorową wizję historii” (Kranz, 2002, s. 41). Zyskując rangę symbolu, oddziałują na wyobraźnię zbiorową, mocno determinując kierunki myślenia o wydarzeniach z okresu wojny czy okupacji. Nie tylko tworzą, ale też utrwalają wyobrażenia do- 
tyczące przeszłości. „Upowszechniane w formie zdjęć, stają się w niektórych przypadkach ikonami pamięci - elementami wyobrażeń i wspomnień dotyczących przeszłości oraz nośnikami określonych doświadczeń” (Kranz, 2002, s. 41).

Do takich miejsc należy niewątpliwie brama prowadząca do Auschwitz I ${ }^{1}$. Jako jedyna została wykonana na rozkaz Niemców przez polskich więźniów politycznych, którzy trafili do obozu na przełomie 1940 i 1941 r. Prowizoryczne ogrodzenie zewnętrzne wsparte na drewnianych słupach wymieniono wówczas na ogrodzenie stałe na słupach żelbetowych z drutem kolczastym pod napięciem. „Witający przybyłych, osławiony napis Arbeit macht frei ${ }^{2}$ odziedziczyło po swoich niemieckich pierwowzorach" (Snyder, 2015, s. 277). Wykorzystane wcześniej w kilku obozach na terenie Trzeciej Rzeszy słowa „Praca czyni wolnym”, pochodzące z tytułu XIX-wiecznej powieści niemieckiego pisarza i pastora Lorenza Diefenbacha, były parafrazą myśli z Ewangelii świętego Jana - „Prawda czyni wolnym”. Napis, który stał się jednym z symboli Auschwitz, przygotowali więźniowie z komanda ślusarzy pod kierownictwem Jana Liwacza - numer obozowy 1010 (Oryginat napisu „Arbeit macht frei”...).

Każdego dnia przez obozową bramę maszerowały do pracy uszeregowane piątkami komanda więźniów. W tym samym układzie następował ich powrót do obozu, jednakże często pięcioosobowy szyk bywał zaburzony, ponieważ więźniowie nieśli wyczerpanych, chorych, zmarłych z wysiłku lub zamordowanych kolegów. Wszyscy byli skrupulatnie liczeni, gdyż stan komand po powrocie musiał się pokrywać z liczbą więźniów, którzy wychodzili rano do pracy. Wracających z niej nieustannie rewidowano, bo więźniowie usiłowali wnieść na teren obozu pożywienie, które udało im się zdobyć poza drutami - m.in. ziemniaki, cebulę, buraki czy chleb (Arbeit macht frei opuścit bramę...). Mijając cyniczny napis umieszczony na obozowej bramie, więźniowie tworzyli ironiczne rymowanki na jego temat. Arbeit macht frei durch den Schornstein, czyli „praca czyni wolnym poprzez komin”; Arbeit macht frei durch Krematorium Nummer drei, czyli „praca czyni wolnym przez krematorium numer trzy" (Miejsca-symbole w bytym niemieckim obozie Auschwitz).

W związku z tym, że Niemcom - mimo podjętych prób zatarcia śladów zbrodni - nie udało się zniszczyć wielu obozowych obiektów, teren Auschwitz-Birkenau był po wojnie stosunkowo dobrze zachowany. Zrodziło to określone konsekwen-

${ }^{1}$ Ogromny ładunek symboliczny zawiera w sobie również brama obozu Auschwitz II-Birkenau, która - podobnie jak ta z Auschwitz I - także przetrwała.

2 Obecnie brama Auschwitz I zwieńczona jest repliką napisu, który został skradziony w 2009 r. Działający na zlecenie szwedzkiego neonazisty złodzieje rozcięli go wtedy na trzy części. Policja odzyskała napis po kilkudziesięciu godzinach poszukiwań. Trafił do obozu, został naprawiony, ale nie wrócił już na dawne miejsce. 
cje w obszarze komemoratywnym. Usytuowane w tym miejscu muzeum stanowi fizyczną przestrzeń przypominanej tragedii. Jak zauważa Anna Maria Wierzbicka - narracja tego miejsca pamięci jest tworzona nie tylko przez nowe działania architektoniczne, podejmowane już po zakończeniu działań wojennych i wyzwoleniu obozu. Mamy tu do czynienia z sytuacją, w której „obiekt staje się świadkiem wydarzenia, a przez to wszedł w sakralną narrację" (Wierzbicka, 2011, s. 447). Tomasz Kranz z kolei odnotowuje, że zachowane ruiny, budynki, autentyczne przestrzenie - zawierające w sobie określony ładunek emocjonalny - „ułatwiają zwiedzającym wyobrażenie sobie zdarzeń, z którymi są związane i ludzi, których dotyczą. W tym kontekście mówi się o "aurze« tych miejsc i olbrzymiej sile, która tkwi w zachowanych reliktach, emanuje w momencie zetknięcia z nimi, determinując silnie sposób postrzegania i przeżywania przeszłości” (Kranz, 2002, s. 40).

Jednak nie wszystkie dawne obozowe przestrzenie funkcjonują tak, jak teren dawnego nazistowskiego niemieckiego obozu Auschwitz-Birkenau. Bywa przecież i tak, że prowadzące do takich miejsc bramy są jednymi z niewielu zachowanych budynków - reliktów świadczących o traumatycznych doświadczeniach więźniów. Tak jest na przykład w przestrzeni dawnego obozu koncentracyjnego Buchenwald. Gdy po wojnie decydowano o demontażu większości obozowych obiektów, jego bramę postanowiono zachować (podobnie jak krematorium i dwie wieżyczki strażnicze). „Budynek bramy obozowej z 1937 roku, z żeliwnymi drzwiami i napisem "Jedem das Seine " (każdemu to, co mu się należy), celami aresztu więźniarskiego oraz zegarem wieżowym, którego wskazówki zatrzymały się na godzinie 15.15, upamiętniać ma akt wyzwolenia obozu przez więźniów politycznych 11 kwietnia 1945 roku" (Sacha, 2013, s. 181). W tym przypadku brama otwiera przed zwiedzającymi rozległą pustkę, w której o wydarzeniach sprzed lat przypominają nieliczne poobozowe budynki. Brama umożliwia wejście do przestrzeni „rozlewającej się przed oczami szarością lub bielą gruntu (w zależności od pory roku) i stapiającej się niewyraźna linią na horyzoncie z lasami” (Sacha, 2013, s. 182).

Niezależnie od tego, czy towarzyszą im jedynie pojedyncze obiekty, czy też otoczone są wieloma innymi autentycznymi budynkami, obozowe bramy stanowią nie tylko przedmiot symboliczny. W przestrzeni konkretnych miejsc pamięci stanowiły bowiem istotny punkt odniesienia, związany z przejściem z jednego świata do drugiego. Wiązały się z tym miejscem określone wspomnienia, dramatyczne doświadczenia dotyczące momentu dotarcia do obozu. Były więzień Gross-Rosen Mieczysław Mołdawa odnotował, że „dominującym akcentem obozu była brama wejściowa z wieżą obserwacyjną. Za nią rozpoczynała się zabudowa: budynki dla przyjęcia nowego transportu więźniów i obiekty zaplecza gospodarczego, potem bloki mieszkalne, a na ich skraju baraki szpitalne i wreszcie kres wędrówki więźnia 
- krematorium” (Mołdawa, 1967, s. 19). W swoich wspomnieniach Mieczysław Mołdawa pisał też, że pierwszą torturą, której w Gross-Rosen doświadczało wiele osób, było „oczekiwanie nieraz całą noc lub cały dzień na ceremoniał przeobrażenia w häftlinga", czyli więźnia (Mołdawa, 1967, s. 83). Wielogodzinne oczekiwanie przy bramie wjazdowej, „widok ludzi katowanych wśród obelg w niezrozumiałym języku, ujadanie psów SS-mańskich, widok znoszenia do rewiru śmiertelnych ofiar robił ogromne wrażenie, był przerażającą wizją przyszłego losu" (Mołdawa, 1967, s. 83). Istotę obozowej bramy i jej miejsce w pamięci więźniów oddają też wspomnienia dotyczące momentu jej przekroczenia, co „następowało zwykle w biegu, wśród bicia, krzyków SS-manów i ujadania psów. "Opieszali«, chorzy i starcy, otrzymywali pierwsze, często śmiertelne rany. Bieg kończył się przed łaźnią. Tam na komendę zrzucano z siebie cywilne ubrania wiążąc je w tobołki. W skwarze letnim czy na mrozie, nadzy popędzani pejczami i szczuci psami - ustawiani byli w równy szereg lub czworobok. Torturowani biciem i przerażeni scenerią oglądanego po raz pierwszy obozu - całymi godzinami czekali na włożenie pasiaka” (Mołdawa, 1967, s. 83).

Dzisiaj brama dawnego obozu koncentracyjnego stanowi przejście do mniej lub bardziej zachowanej przestrzeni historycznej. Wprowadza w obszar artefaktów, reliktów i obiektów, ale też w obszar wytworzonych wśród nich wspomnień. Oddziela ją od świata zewnętrznego i - jak powie Aleida Assmann - od nagle przerwanej historii. Jej zdaniem „w miejscu pamięci określona historia nie poszła dalej, lecz została mniej lub bardziej gwałtownie przerwana. Przerwana historia materializuje się w ruinach i reliktach, które odbijają się od otoczenia jako obce pozostałości. To, co przerwane, zastygło w pozostałościach i pozostaje bez związku do lokalnego życia teraźniejszości, które nie tylko potoczyło się dalej, lecz przeszło nad tymi pozostałościami - z mniejszą lub większą nieuwagą - do porządku dziennego" (Kranz, 2002, s. 40).

\section{Marsz Żywych}

Współczesne doświadczenie przekraczania granicy wyznaczanej przez obozową bramę jest wstępem do całego procesu zbiorowej terapii, będącej konsekwencją traumatycznych wydarzeń z przeszłości. Terapię tę należy widzieć w tym przypadku zarówno w wymiarze indywidualnym, jak i grupowym. Odnosi się ona do całych grup społecznych, zarówno narodowych, jak i przekraczających granicę jednego tylko narodu. Widzimy to zresztą także w wielu innych przejawach rytualnego „przejścia”, które wymagają podjęcia określonej aktywności, prowadzą- 
cej do przeżycia osobistego doświadczenia odnoszącego się do przypominanych wydarzeń. Działania te wpisują się w obszar rytuałów czy widowisk służących nie tylko pielęgnowaniu pamięci i przeżywaniu przeszłości, ale też nadawaniu jej znaczenia w teraźniejszości. Dotykamy tu istoty miejsc pamięci. Jak ujął to niemiecki historyk Günter Morsch - nie mogą być one miejscami, w których historia jest odłożona na półkę. Muszą mieć wpływ na teraźniejszość, a to znaczy, że nie mogą ograniczać się jedynie do zbierania świadectw z minionych czasów. Odnoszące się do przeszłości dążenie do prawdy historycznej musi być tutaj powiązane z poszukiwaniem podobieństw z teraźniejszością (Netzwerk der Erinnerung, s. 65).

Same w sobie - nawet najwierniej zachowane - obiekty świadczące o traumatycznych wydarzeniach nie są wystarczające dla zachowania wspomnień i wyciągania z nich wniosków. Do osiągnięcia tego celu niezbędna jest bowiem aktywność osób, które owe wspomnienia mają pielęgnować i uwzględniać w refleksji budującej mosty między przeszłością a teraźniejszością. Wynika to z faktu, że pamięć to nie tylko reprezentacja przeszłości, ale też działanie komunikacyjne. Jak zauważa Sławomir Kapralski - „właśnie ów aktywny aspekt pamięci sprawia, że wynaleziona tradycja przekształca się w dyskurs popularny i zmienia indywidualne wspomnienia w pamięć zbiorową" (Kapralski, 2012, s. 319). Proces ten wspierają różnego rodzaju spektakle i widowiska, które mają rytualny charakter i z reguły wykorzystują duży ładunek symboliczny odnoszący się do wspomnień. Za Izabelą Skórzyńską możemy powiedzieć, że „jeśli w repertuarze symbolicznym danej wspólnoty pojawia się widowisko, znaczy, że dokonuje się tu jakaś przemiana, która przybiera postać procesu wyrażonego w działaniu. Jeśli pomnik, architektura, muzeum w tradycyjnym sensie są świadectwami tego, że coś zostało zapamiętane, to widowisko świadczy o tym, że jest nadal jakoś rozpamiętywane (rozgrywa się dramat społeczny)" (Skórzyńska, 2007, s. 84).

Przykładem takiego aktywnego rozpamiętywania - w czytelny sposób wykorzystującego interesującą nas figurę symbolicznego „przejścia” - są organizowane od 1988 r. Marsze Żywych, odbywające się na terenie Auschwitz-Birkenau w Dzień Pamięci o Zagładzie. Biorą w nich udział m.in. przywódcy państwowi, reprezentanci rządów i parlamentów, dyplomaci, przedstawiciele Kościołów, a także uczniowie ze szkół w Izraelu i Polsce. Upamiętniają ofiary Holokaustu, a także przypominają tych, którzy mieli odwagę przeciwstawić się złu i - jak stwierdził prezydent Izraela Ezer Weizman - „którzy odczuwali ból prześladowanych, którzy narażali życie swoje i swoich bliskich i dawali im kromkę chleba i szklankę wody, którzy udzielali schronienia" (IX Marsz Żywych).

Uczestnicy Marszu Żywych pokonują trasę z terenu Auschwitz I do Auschwitz II-Birkenau. Wyruszają spod bramy Arbeit macht frei i biorą udział w ceremonii 
przy pomniku upamiętniającym ofiary obozu, wzniesionym w pobliżu ruin komór gazowych i krematoriów. Idąc tą drogą, przywołują przerażające doświadczenie tych, którzy nie przeżyli obozowego dramatu. Co ważne - czynią to jako żyjący. Manifestują fakt, że nazistom nie udało się zrealizować planu wymazania całego narodu czy całych grup etnicznych z mapy świata. W czasie jednej z dorocznych ceremonii w Auschwitz zwracał na to uwagę ocalały z Holokaustu Meir Lau, były główny rabin Izraela. W ten sposób opisywał proces ponownego „przejścia” po przepełnionym traumą obozowym terenie Auschwitz: „Tak, jak przed laty nasi ojcowie, bracia i siostry szli ostatnią drogą, z której nie było powrotu, my bierzemy dziś udział w Marszu Żywych, a nie w marszu śmierci. I każdy z nas powróci do domu, do swojej ojczyzny. To daje nadzieję, napawa dumą i jest pozytywne" (21. Marsz Żywych).

Wyraźnie więc widać, że - jak podkreśla dyrektor Muzeum Auschwitz Piotr Cywiński - marsze te nie są jedynie lekcją historii. Wpisują się one w rozpamiętywanie, którego cel wykracza daleko poza podstawowe rozumienie edukacji. „Przejście przez autentyczny poobozowy teren to bowiem czas niezwykle ważnej refleksji. Właśnie w Auschwitz najpełniej można zmierzyć się z najważniejszymi pytaniami o człowieka, o społeczeństwo, o skutki pogardy, nienawiści czy antysemityzmu" (Sawicki, 2017, s. 3). Ponowne zanurzenie się w obozowej przestrzeni, symboliczne pokonanie traumatycznej drogi - rytualne „przejście” w Marszu Żywych nie służy jedynie przekazywaniu kolejnym pokoleniom prawdy o nazistowskiej niemieckiej zbrodni. Celem jest nie tylko pielęgnowanie pamięci, ale też wykorzystywanie jej we współczesnych procesach społecznych i politycznych. Zwracał na to uwagę prezydent Izraela Reuven Rivlin, składając w Auschwitz jasną deklarację: „Ci, którzy są gotowi patrzeć odważnie w swą przeszłość, ci którzy gotowi są stawić czoła antysemityzmowi, rasizmowi, który nawet dzisiaj podnosi swój łeb, znajdą w nas sojuszników - zdeterminowanych, prawdziwych partnerów, którzy będą prowadzić dalej drogę od pamięci ku przyszłości" (27. Marsz Żywych z udziatem Prezydentów Polski i Izraela). Podobne deklaracje składali biorący udział w Marszach Żywych przedstawiciele rządów, na przykład ministrowie edukacji Polski i Izraela, którzy w 2017 r. we wspólnej deklaracji zobowiązywali się „pamiętać i upamiętnić miliony żydowskich ofiar Holokaustu, ludobójstwo przedstawicieli narodowości romskiej, jak również inne masowe okrucieństwa związane z Holokaustem". W ogłoszonym wówczas dokumencie zapowiadali: „Będziemy szanować ocalałych, którzy wciąż są z nami i oddawać cześć tym, którzy sprzeciwiali się złu nazistowskiej tyranii. Zobowiążemy się do zwalczania wszelkich form negowania Holokaustu, a także zwalczania antysemityzmu, uprzedzeń w stosunku do Romów i wszystkich form rasizmu i nietolerancji” (26. 
Marsz Żywych. Deklaracja pamięci ministrów edukacji). Tego typu deklaracje wyraźnie potwierdzają, że „wspomnienia Holokaustu ułatwiają kształtowanie się ponadnarodowych kultur pamięci, które z kolei mogą stać się kulturową podstawą globalnej polityki praw człowieka” (Levy, Sznaider, 2002, s. 88).

\section{Auschwitz jako pomnik-droga}

Figura „przejścia” służy często rekonstruowaniu wydarzeń historycznych, czego efektem ma być upamiętnienie ich ofiar i oddanie hołdu ich bohaterom. W przypadku Auschwitz-Birkenau taka koncepcja „przejścia” pojawiała się zresztą także na etapie poszukiwania i opracowywania różnych propozycji upamiętnienia dramatu tego miejsca. Tak było chociażby w 1958 r., gdy zorganizowano konkurs na koncepcję upamiętnienia ofiar hitlerowskiego obozu. Gdy Międzynarodowy Komitet Oświęcimski postanowił wybrać projekt Pomnika Ofiar Faszyzmu, swój pomysł zgłosił zespół pod kierunkiem Oskara Hansena, który zaproponował stworzenie długiej wstęgi - drogi mającej prowadzić pomiędzy obozowymi barakami. Wytyczając jej przebieg, projektanci nałożyli ją na plan KL Auschwitz-Birkenau II pod kątem około 45 stopni, kilkanaście centymetrów ponad ziemią. To właśnie z perspektywy tej drogi zwiedzający mieliby przyglądać się pozostałościom obozu. Jak przekonywał jeden z twórców koncepcji Jerzy Jarnuszkiewicz - „W tych warunkach współautorem pomnika należy uczynić odbiorcę, człowieka odwiedzającego obóz, nasz udział zaś sprowadzić do roli przewodnika, czy może raczej reżysera, który by nakreślił linię przewodnią, uwypuklił najbardziej ważkie elementy tego dramatycznego spektaklu" (Cymer, 2019). Droga przecinająca teren obozu miała ukazywać jego mechanizm, ale nie chodziło tu jedynie o bierną obserwację. Kroczenie wyraźnie wytyczoną ścieżką miało nakłaniać do interakcji, uczestnictwa, spontanicznych gestów. „Jeśli ktoś będzie chciał zostawić kartkę z imieniem lub figurkę anioła, może to zrobić obok drogi" - przekonywali autorzy koncepcji (Wierzbicka, 2011, ss. 447-449).

Skupili się na próbie przeprowadzenia zwiedzających przez obóz w określonym rytmie - od dawnej wartowni po ruiny krematorium II. Zaproponowane „przejście” było związane z próbą odtworzenia doświadczeń uczestników traumatycznych wydarzeń przez wyznaczenie widocznej ścieżki, dającej się eksplorować swoistej mapy naniesionej na obozowy teren. I ten właśnie plan nie dla wszystkich był do zaakceptowania. Żyjące ofiary Auschwitz widziały w tym pomyśle modyfikowanie, przekształcanie „mentalnej mapy” tego miejsca. A taką właśnie mentalną, indywidualną mapę nosił w sobie każdy, kto przeżył obozowy dramat. 
Projekt tak rozumianego „pomnika-drogi” nie został więc ostatecznie zrealizowany, stanowił jednak ważny głos w dyskusji na temat przestrzeni miejsc pamięci nie tylko doceniał siłę krajobrazu, ale też wskazywał, że dosłowność można w tych miejscach zastąpić nastrojem i wiele mówiącą, syntetyzującą przekaz symboliką (Wierzbicka, 2011, s. 449; Kozakiewicz, 2017).

\section{Bełżec, Majdanek, Treblinka}

W wielu miejscach pamięci zrekonstruowanie ich mapy i odtworzenie tkanki traumatycznej przestrzeni stało się realnym wyzwaniem. Między innymi tam, gdzie jeszcze w czasie wojny Niemcy zaczęli zacierać ślady swoich zbrodni. „Z masowych grobów wydobywano ciała zamordowanych i palono je na odkrytych stosach spaleniskowych. Demontowano urządzenia i prowizoryczne budynki, a następnie transportowano je do Lublina. Tereny zajmowane przez ośrodek zagłady Treblinka, Bełżec czy Sobibór zniwelowano, zaorano, obsadzono drzewami lub obsiano roślinami uprawnymi. $\mathrm{Na}$ ich miejscu założono gospodarstwa rolne" (Szuchta, 2015, s. 252).

$\mathrm{Z}$ czasem ofiary tych miejsc doczekały się różnych form upamiętnienia. Prowadzono tam badania archeologiczne, odkrywano fundamenty budynków obozowych, dokumentowano zbrodnie, wznoszono pomniki. Odtwarzając topografię tamtych obozów, również wykorzystywano figurę „przejścia”. Przygotowując kompleks muzealno-pomnikowy na terenie byłego niemieckiego, nazistowskiego obozu zagłady w Bełżcu, zdecydowano się stworzyć przestrzenny Cmentarz-Pomnik, którego koncepcja wyraźnie koresponduje z niezrealizowaną w Auschwitz myślą zespołu Hansena. „Ascetyczne założenie o linearnym następstwie zdarzeń (wejście przejście wyjście), zostało ukształtowane jako eksterytorialne "pole«, pokryte szaro czarnym wielkopiecowym żużlem i wyjałowioną ziemią. W tej "pustce« widz poddany jest bardzo silnym fizycznym doznaniom: zagubienia, samotności, strachu i niepewności" (Miejsce Pamięci na terenie bytego Hitlerowskiego Obozu Zagtady Żydów, Betżec).

Wiele w tym miejscu symboli zbiorowej mogiły - m.in. oznaczono miejsca lokalizacji masowych grobów. Mur cmentarny prowadzi nas w stronę rzeźbiarskiej kompozycji stworzonej ze zdemontowanych podkładów kolejowych. Przywołuje ona stos, na którym załoga obozu paliła zwłoki ofiar. Główne wejście na cmentarzysko usytuowano w miejscu, w którym znajdowała się bocznica kolejowa. „Rampa” wprowadza zwiedzających na „Drogę” prowadzącą w stronę „Szczeliny”, która wygląda niczym pęknięcie w ziemi. To przypominające wąwóz coraz głębsze 
przejście, które pozwala wniknąć w zbiorową mogiłę i dotrzeć do wysokiej granitowej ściany, prezentującej fragment biblijnej Księgi Hioba: „Ziemio, nie kryj mojej krwi, iżby mój krzyk nie ustawał". Jest tu też usytuowane 9 metrów pod ziemią miejsce kontemplacji - Nisza Ohel - gdzie na kamiennych tablicach wykute zostały imiona ofiar obozu. Monumentalną przestrzeń miejsca pamięci w Bełżcu uzupełnia betonowa ścieżka, na której poznajemy nazwy miejscowości i gmin żydowskich, z których przywożono tutaj więźniów. Są też jeszcze schody prowadzące na górną granicę pomnika, które mogą być odczytywane jako element wskazujący perspektywę nadziei (Pomnik i jego symbolika; Gębczyńska-Janowicz, 2010, s. 72).

Autorzy tej koncepcji upamiętnienia zaproponowali zwiedzającym zanurzenie się w historii opowiadanej z perspektywy ofiar. Wymagająca tu pokonania droga rekonstruuje przeszłość, którą sprawcy próbowali zatrzeć, wymazać, poddać zapomnieniu. Dzięki takiemu wniknięciu w poobozową przestrzeń nieobecni znów stają się symbolicznie obecni - choć w ciszy i pustce, z którą zmagają się ci, którzy trafiają w to miejsce, by przywoływać dawną traumę.

Podobny proces możemy zauważyć w otoczeniu Pomnika Walki i Męczeństwa na Majdanku, gdzie pomnikowe rzeźby i zrekonstruowane obozowe obiekty zostały połączone drogą, której pokonanie ma w odwiedzających to miejsce pamięci wywoływać poczucie zmęczenia, opresji i niewygody. Dyskomfort i lęk może być pogłębiony monumentalnym charakterem budowli, które tutaj wzniesiono. Już u wejścia na teren dawnego obozu przytłaczać może symboliczna brama, której nadano formę potężnej, ciężkiej i abstrakcyjnej bryły. Inspiracją dla jej stworzenia stały się słowa dramatu Dantego o ludziach tracących całą nadzieję po przekroczeniu bramy. Umieszczono w niej wąskie przejście, które wymaga niemal namacalnego spotkania z głazami wiszącymi ponad głowami wchodzących w tę przestrzeń. Może to budzić w nich niepokój, podobnie jak znajdujące się nieopodal nieergonomiczne schody prowadzące do ponadkilometrowej drogi, wzdłuż której stoją odtworzone obozowe zabudowania - baraki, wieże strażnicze, ogrodzenie. Na końcu drogi z kolei wzniesione zostało mauzoleum z prochami ofiar obozu - wsparta na słupach kopuła, stojąca tam, gdzie w czasie wojny działało krematorium. Wykuty na budynku napis głosi: „Los nasz dla was przestrogą”. Tak skonstruowane monumentalne miejsce refleksji wymusza aktywność zwiedzających, przywołując na myśl doświadczenia więźniów obozu. Wynika to z faktu, że za kompozycyjną oś upamiętnienia przyjęto tutaj topografię historycznego miejsca traumatycznych doświadczeń - ciąg komunikacyjny, który łączył obóz z miejscem kaźni (Gębczyńska-Janowicz, 2010, s. 69).

Nieobecność reliktów i pytania o rekonstrukcję śladów materialnych to wyzwanie, z którym zmagali się też twórcy koncepcji upamiętnienia ofiar obozu zagła- 
dy w Treblince. Widoczną na jego terenie pustkę wypełnili reprezentacjami, które mają wspierać przyswajanie przeszłości - szczególnie na poziomie emocji, zmysłów i refleksji. Tu także pojawia się brama wejściowa - w sposób symboliczny zrekonstruowana za pomocą dwóch betonowych bloków. Jest również droga łącząca rampę kolejową i komory gazowe. Wchodząc w tę przestrzeń i poruszając się ścieżkami wyłożonymi ostrymi kamieniami, zwiedzający trafiają też m.in. do Ściany Płaczu oraz dotykają miejsca, w którym spalane były ofiary obozu (Wysok, 2015, s. 22). Układ symbolicznej drogi, którą tutaj zrekonstruowano, pomaga w odtworzeniu nastroju rozpaczy, grozy i bólu. Rodzi konkretne doznania, ponieważ - jak zauważa Agnieszka Gębczyńska-Janowicz - „obserwator przestaje być pasywnym odbiorcą inscenizacji tragedii, zaczyna uczestniczyć $\mathrm{w}$ wędrówce $\mathrm{w}$ przestrzeni, w której tysiące ludzi szło na śmierć. [...] Przybywający do Treblinki, przekraczając bramę założenia, wstępują w starannie wyreżyserowaną scenerię upamiętniania" (Gębczyńska-Janowicz, 2010, s. 66). W obrazowy sposób ujęła to Irena Grzesiuk-Olszewska, która stwierdziła, że przestrzeń komemoratywna w poobozowej rzeczywistości Treblinki „sprawia wrażenie pochodu donikąd, widmowej pielgrzymki setek tysięcy istot ludzkich idących na śmierć” (Wysok, 2015, s. 44). Wszystko to przywołuje skalę dramatu, który rozegrał się w tym miejscu oraz uświadamia otchłań i bezsens okrucieństwa, jakie zrodziło się z radykalnego zła.

W drugiej połowie lat 80 . XX w. powstał nowy projekt zagospodarowania terenu i rozbudowy Muzeum Walki i Męczeństwa w Treblince. I choć nie został ostatecznie zrealizowany, warto przywołać w tym miejscu jego założenia, albowiem doskonale wpisują się w interesujący nas sposób myślenia o figurze „przejścia” w koncepcjach komemoratywnych. Architekci, którzy opracowali ten projekt (Henryk Kosieradzki i Krzysztof Ołdziejowski), proponowali konstrukcję wykorzystującą nagromadzenie i zagęszczenie betonowych słupów, belek, stropów oraz zacieśniających się i rosnących ścian. W tym projekcie „zwiedzający są prowadzeni kamienną posadzką w kierunku wejścia do szczeliny. Ciemne i ciasne przejście sprowadza do wysokiego pomieszczenia doświetlonego górą z nachylonymi ku sobie ścianami (sztuczna perspektywa w celu spotęgowania wrażenia wysokości). Forma jest odtworzeniem refleksji wobec zagrożenia i niepewnej przyszłości" (Zawadka, 2015, s. 51). Autorzy tej koncepcji chcieli m.in., by zwiedzający przechodzili pochylnią do podłużnych pomieszczeń, które miały budzić skojarzenia z pociągami, jakimi wcześniej transportowani byli więźniowie obozu. Trafiali z nich na rampę, gdzie byli wyładowywani i gdzie większość z nich zyskiwała świadomość zbliżającej się nieuchronnie śmierci. Symbolem tej sytuacji - zgodnie z planowaną inscenizacją miejsca pamięci - miało być przejście zwiedzających do pomieszczenia w formie klatki. „Jego zachwiana geometria oddaje wstrząs świa- 
domości w obliczu tego faktu. Posadzka pogrąża się w szczelinie rampy prowadząc do ciągu trzynastu komór - symbolu komór gazowych, gdzie znajdują się zachowane szczątki ofiar. Zakręcający korytarz otwiera się do kaplicy - miejsca skupienia i kontemplacji przeżyć, które stały się udziałem miliona ludzi. Wyjście z kaplicy następuje unoszącą się ślimacznicą - pochylnią na powierzchnię terenu, z widokiem na symboliczną bramę b. obozu zagłady" (Zawadka, 2015, s. 51).

\section{Memoriał Ofiar Komunizmu w Tallinie}

Zaproponowana - choć niezrealizowana - koncepcja upamiętnienia ofiar obozu zagłady w Treblince odnosi się do myślenia o figurze „przejścia”, która może być nie tylko naturalnym, materialnym elementem architektonicznym wpisanym w historię miejsca upamiętniającego wydarzenia z przeszłości. Nie zawsze musi to być relikt, artefakt, obiekt, który swoją historią przywołuje wspomnienia. Niejednokrotnie owo „przejście” może stanowić element symboliczny, który ma narzucać pewną wizję lub zapraszać do określonego doświadczenia w miejscu pamięci. Tak jest właśnie w przypadku Memoriału Ofiar Komunizmu w Tallinie. Wykorzystano w nim wysoki mur składający się z dwóch betonowych ścian, obłożonych ciemnymi, metalowymi płytami. Umieszczone w niedużej odległości tworzą dwustumetrowy korytarz, który stanowi alegorię okresu walki z terrorem komunistycznym i przywołuje na myśl zderzenie konkretnych osób - ofiar reżimu $-\mathrm{z}$ brutalnym systemem. Ich nazwiska zostały udokumentowane poprzez napisy umieszczone na ścianach korytarza (Memorial for the Estonian Victims of Communism).

Wejście w tę przestrzeń oznacza rozpoczęcie symbolicznej wędrówki, która w odwiedzających może wywoływać poczucie osamotnienia czy izolacji. Może to być również dyskomfort czy doświadczenie zderzenia z nieprzyjaznymi wydarzeniami z przeszłości. Następuje po nich jednak kolejny etap - czas pokoju i bezpieczeństwa, czego symbolicznym wyrazem jest ogród, do którego prowadzi pomnikowy korytarz. Twórcy tego miejsca pamięci w ten sposób podkreślili, że trwająca przez kilka dekad i okupiona życiem wielu osób walka z systemem komunistycznym doprowadziła do realizacji marzenia o wolności (Home Garden).

W ogrodzie posadzono owocujące jabłonie, tworzące przestrzeń życia. Z kolei na zewnętrznej ścianie monumentu - od strony ogrodu - umieszczono 28 tysięcy małych rzeźb, odlewów pszczół, symbolizujących ofiary sowieckich represji. To nawiązanie do słów estońskiego poety Juhana Liiva, który życie narodu opisywał za pomocą metafory pszczół wracających do ula. Wiedział, że nie wszystkie docie- 
rają do celu i przypominał o tym, kiedy mówił o ludziach walczących z sowieckim reżimem. Wielu z nich przecież także zginęło w drodze, tęskniąc za ojczyzną, nie doczekawszy wolności (A Memorial for Communism Victims of Estonia is Opened Tommorow in Maarjamäe).

Próbując odczytać symbolikę tallińskiego monumentu, możemy stwierdzić, że zastosowane tutaj „przejście” nie jest drogą prowadzącą w jednym tylko kierunku. Naturalnym wydaje się, że pomnikowy korytarz wiedzie do ogrodu - prowadzi więc do bezpiecznego miejsca. $Z$ drugiej jednak strony ten sam ogród może być też początkiem drogi, czego dowodzi opis projektu monumentu, w którym czytamy, że „aby dotrzeć do ogrodu, trzeba wyruszyć w podróż. Aby wyruszyć w podróż, trzeba opuścić ogród”. A zatem ci, którzy podejmowali walkę z „zimnym", bezdusznym systemem, opuszczali swoją strefę bezpieczeństwa i wnikali we wrogi świat, który nierzadko ich pokonywał. „Ludzie zostali siłą zabrani z domu i zmuszeni do kroczenia ścieżką cierpienia. Tylko niektórzy z nich byli w stanie je przetrwać i wrócić do ogrodu" - podkreśla Estoński Instytut Pamięci Historycznej (A Memorial to the Victims of Communism Opens in Estonia).

\section{Pomnik Pomordowanych Żydów Europy}

Symboliczną figurę „przejścia”, wpisaną w przestrzeń pomnikową, możemy też dostrzec $\mathrm{w}$ Berlinie, $\mathrm{w}$ jednym $\mathrm{z}$ centralnych miejsc pamięci odnoszącej się do wydarzeń okresu II wojny światowej. Chodzi o Pomnik Holokaustu, który 60 lat po zakończeniu wojny został wzniesiony w centrum miasta, na placu liczącym 19 tysięcy metrów kwadratowych, między Bramą Brandenburską a Placem Poczdamskim. Składa się z około 2700 stel o różnej wysokości; najniższe mają zaledwie 20 centymetrów, a te najwyższe sięgają niemal 5 metrów. To labirynt betonowych kolumn ustawionych w odległości niecałego metra, „pomiędzy którymi zdoła przejść tylko jeden człowiek - co winno symbolizować doświadczenie samotności i strachu" (Kula, 2002, s. 175). Owa samotność ma prowadzić do osobistego spotkania z historią i indywidualnego z nią rozrachunku - uzależnionego od wrażliwości i wyobraźni poszczególnych osób odwiedzających to miejsce. Jego gospodarze zachęcają do tego, aby „zanurzyć się w tej w pełni spacerowej konstrukcji” - dostęp do niej jest otwarty z każdej strony. Nie ma tu jednego wejścia czy wyjścia. Nie trzeba też pokonywać żadnych barier, żeby się do niego dostać, albowiem pomnik został wpisany w przestrzeń miejską. Nie został od niej odseparowany - przeciwnie, zgodnie z pomnikowym założeniem jest jej integralną częścią, współtworzy ją, kreuje. 
Obcowanie z gąszczem szarych, ponurych, kamiennych bloków, których po wejściu w pomnikową przestrzeń - nie da się ogarnąć wzrokiem, może być wymagającym doświadczeniem. Gdy bowiem z pewnej odległości i z dystansu patrzymy na ważące po kilka lub kilkanaście ton stele, mogą one sprawiać wrażenie ciemnego, spokojnego oceanu. Jednakże „zanurzenie się” w ten ocean, czyli wejście w głąb pomnika, może prowadzić do zburzenia wizji - jak się okazuje - pozornego tylko spokoju. Przejściu przez labirynt kamiennych bloków może towarzyszyć poczucie zagubienia, dezorientacji i izolacji, a nawet grozy. Wzmaga ją nieregularne ułożenie terenu, na którym wzniesione zostały betonowe bloki, co burzy poczucie stabilności i bezpieczeństwa. Wszystko to wpływa na emocjonalno-zmysłowy odbiór pomnikowego przesłania, prowadzący do refleksji nad niepojętością zbrodni oraz nad winą i odpowiedzialnością (Zaborski, 2011, s. 132).

Jednakże samo wskazywanie winnych nie było zamysłem autora Pomnika Pomordowanych Żydów Europy. Peter Eisenman wyszedł z założenia, że jego koncepcja powinna raczej pozwolić wczuć się w sytuację prześladowanego, osamotnionego Żyda. Według architekta - „ludzie zauważą, że tutaj oferuje się inne przestrzenne doświadczenie aniżeli we wszystkich innych znanych miejscach. Chcemy dać ludziom, być może na moment, uczucie, jak mogłoby być, gdyby stali na straconej pozycji, gdyby chwiał się grunt pod nogami, gdyby byli izolowani od swego otoczenia. Nam nie chodzi o wskazanie winy lub czegoś podobnego. My chcemy, by zwiedzający wspomnieli elementarne osobiste doświadczenie, które mieli, będąc tutaj" (Wolff-Powęska, 2011, s. 389).

Szczególny nacisk położony został więc tutaj na żywą pamięć indywidualnego doświadczenia. Eisenman uznał, że rozumienie przeszłości jest możliwe jedynie za sprawą jej zamanifestowania w teraźniejszości. Odwołał się przy tym do myśli Marcela Prousta, który wyróżnił dwa rodzaje pamięci. Z jednej strony odnotował odnosząca się do przeszłości nostalgię połączoną z sentymentalizmem, który nie pamięta rzeczy takimi, jakimi były naprawdę, ale pamięta je tak, jak chcemy je zapamiętać. $Z$ drugiej natomiast strony - w powieści W poszukiwaniu straconego czasu mowa jest o żywej pamięci, aktywnej w teraźniejszości i wolnej od nostalgii za wspominaną przeszłością. To rozróżnienie jest ważne dla Eisenmana w odniesieniu do Zagłady. Nie można bowiem, jego zdaniem, wspominać tych tragicznych wydarzeń z sentymentalną nostalgią. „Horror Holokaustu na zawsze zatarł związek nostalgii i pamięci. Pamięć o Holokauście może mieć tylko żywą formę, w której przeszłość pozostaje aktywna w teraźniejszości" (Peter Eisenman über das Denkmal)³.

${ }^{3}$ Dlatego też celem „przejścia” - wniknięcia w przestrzeń Pomnika Holokaustu - nie jest znalezienie odpowiedzi na określone pytania, a raczej samo ich stawianie. Podobnie zresztą jak w upa- 
W przypadku Pomnika Pomordowanych Żydów Europy istotą obcowania z kamiennymi bryłami staje się kontemplacja, przeżywanie i przywoływanie wydarzeń niedających się w pełni zrozumieć i wytłumaczyć. Ten sposób opowiadania o roli współczesnych miejsc pamięci wpisuje się w nurt myślenia o nich jako miejscach edukacji i kształtowania postaw społecznych. Chodzi zatem - jak ujmuje to Tomasz Kranz - „nie tylko o poznawanie wydarzeń i zjawisk historycznych, a więc edukację historyczną, ale również o projekcję uzyskanej i poddanej odpowiedniej analizie wiedzy do świata współczesnego. Ten rodzaj edukacji nazywany jest powszechnie kształceniem społeczno-politycznym. Jest to forma wychowania obywatelskiego, mocno osadzona w sferze wewnętrznych przeżyć i indywidualnych odczuć” (Kranz, 2000, s. 61). Pomnikowa formuła „przejścia” a także związane z nią przyjęcie zaproszenia do obszaru upamiętnienia i przebycie odpowiedniej drogi zaproponowanej przez autorów czy gospodarzy miejsca pamięci - wspiera procesy przeciwdziałania uprzedzeniom, uczy tolerancji, pomaga przełamywać stereotypy i budować szacunek dla różnic między ludźmi, ułatwia rozumienie problemów współczesnego świata, ugruntowuje krytyczne myślenie czy wreszcie kreuje odpowiedzialność społeczną.

\section{Pomnik Anonimowego Przechodnia}

Figura „przejścia” zastosowana w przestrzeni pamięci nie zawsze musi mieć wymiar realnej aktywności oczekiwanej od odbiorcy. Uczestnictwo w tym rytuale może przybierać także formę symboliczną - ograniczoną do obserwacji. Tak jest wówczas, gdy obcujący z pomnikiem czy miejscem pamięci nie muszą się przemieszczać, a jedynie są nakłaniani do refleksji i wejścia w pewną relację z artystyczną kompozycją o określonym przesłaniu.

Proces ten widzimy na przykład w konstrukcji stworzonej przez Jerzego Kalinę, który w latach 70. XX w. zaproponował instalację wykorzystującą gipsowe, szare figury zwykłych ludzi (wśród nich matka z dzieckiem czy staruszka) zaopatrzonych w pospolite rekwizyty (na przykład wózek dziecięcy, laska, torba, parasol). Pierwszy raz zaprezentowano ją w nocy z 12 na 13 grudnia 1977 r. u zbiegu ulic

miętnianiu nie chodzi jedynie o pomnik czy muzeum. Równie istotny, a dla wielu wręcz kluczowy, jest sam proces dochodzenia do finalnego etapu zwieńczonego wzniesieniem monumentu czy miejsca pamięci. Celem jest więc nie tylko dotarcie do celu, ale też samo pokonywanie prowadzącej do niego drogi, czyli na przykład prowadzenie często ostrych debat i sporów, stawianie mało komfortowych pytań i mierzenie się z niewygodnymi z punktu widzenia zbiorowości dylematami (Rolloff-Momin, 1994, s. 92). 
Mazowieckiej i Świętokrzyskiej w Warszawie, na potrzeby telewizyjnego programu Vox Populi. Burząca codzienny porządek miejskiej przestrzeni instalacja miała prowokować dyskusję wśród przechodniów i zderzać ich z pytaniem o granicę i istotę sztuki. Figury postaci wyłaniających się spod płyt chodnikowych lub znikających pod nimi budziły w wielu odbiorcach skojarzenia z okupacyjną rzeczywistością. Dla innych były ilustracją szarej codzienności PRL-u i politycznej rzeczywistości, w której losem wielu było zejście do podziemia i walka o wolność. Po latach dostrzeżono w nich też swoistą przepowiednię, co ma związek z datą pierwotnej prezentacji instalacji Kaliny. Działo się to przecież dokładnie 4 lata przed ogłoszeniem stanu wojennego, w czym widziano wręcz profetyczną zapowiedź dramatycznych wydarzeń Grudnia '81 (Szafkowska, Pomnik Anonimowego Przechodnia).

Pomnikowa instalacja Jerzego Kaliny umożliwia też jednak zupełnie odmienne interpretacje, o czym mówi sam autor dzieła: „Oczywiście odnosiło się do znikania, indywidualnego i zbiorowego, ale chodziło mi raczej o taką polską przypadłość zapadania w śpiączkę chocholą. Ale praca miała mieć wymiar optymistyczny, bo przecież tłum, wchodząc po jednej stronie, jednak po drugiej stronie się pojawia. Ten exodus ma jakiś sens" - tłumaczył twórca Przejścia, proponując spojrzenie na tę pracę przez pryzmat uniwersalnego pytania o kondycję człowieka. Skierował naszą uwagę nie tylko na zmagania zwykłego człowieka z codziennością i dotykającymi go zmianami, ale też na fakt mierzenia się z tymi trudnościami nie samodzielnie, ale we wspólnocie. Przekonywał, że to w niej tkwi siła, która doświadczającym tych przeciwności pozwala wydostać się na powierzchnię (Przejście. Jerzy Kalina).

Po wielu latach stworzone przez Kalinę figury zostały utrwalone w brązie i w 24. rocznicę wprowadzenia stanu wojennego stanęły w centrum Wrocławia jako Przejście 1977-2005, a także jako Pomnik Anonimowego Przechodnia. Umieszczone po jednej ze stron arkad ulicy Świdnickiej naturalnej wielkości postaci zapadają się pod ziemię i wyłaniają się z chodnika po drugiej stronie ulicy. Rzeźby są w ruchu. Dokonują tytułowego „przejścia”. Wrocławskie władze zdecydowały się na takie upamiętnienie z myślą o zwykłych ludziach, którzy „przez dziesiątki lat czuli ciężar systemu komunistycznego, niedostatku, absurdu i upokorzenia, a mimo to potrafili go pokonać” (Zaborski, 2006, s. 18).

Wykorzystywana w przestrzeni komemoratywnej figura „przejścia” ma wielowymiarowy charakter. Jej poszczególne przejawy rodzą odmienne skojarzenia i skutki w obiektach pomnikowych czy miejscach pamięci. Bramy - poza ich oczywistymi odwołaniami do historii - mogą być widziane jako metaforyczne punkty przejścia, które przenoszą nas z przestrzeni codziennej do odświętnej rzeczywistości 
upamiętniania. Używany w niej element drogi to z kolei sposób na wymuszenie w odbiorcach określonej aktywności, kreatywnego udziału w procesie wspominania czy przywoływania ofiar. Odwiedzający miejsce pamięci stają się w tym przypadku niejako pielgrzymami, dla których przewidziano pewien ciąg doświadczeń. Dzięki drodze następuje uporządkowanie procesu poznawczego i emocjonalnego - m.in. przez wyciszanie odbiorcy i mentalne przygotowywanie go na dotarcie do kulminacyjnego punktu upamiętnienia. Z kolei korytarze i szczeliny mają charakter opresyjny - wywołują w zwiedzających poczucie osamotnienia, izolacji, pustki i wyłączenia ze świata zewnętrznego. W ten sposób tworzą przestrzeń refleksji i nakłaniają do stawiania pytań - nie tylko o doświadczenia historyczne, ale też o ich aktualność we współczesnym świecie. Przejawia się w tym ich uniwersalny charakter. „Przejście” wpisane w przestrzeń pomnikową może też być wreszcie symbolem zachodzących zmian i procesów społecznych, opisując je w sposób ikonograficzny. Z kolei tym, co łączy wszystkie te figury, jest niewątpliwie ich istotny udział w budowaniu i pielęgnowaniu - ważnych dla trwania i rozwoju wspólnoty - mostów między przeszłością a teraźniejszością.

\section{Bibliografia:}

21. Marsz Żywych. (2012). Pobrano z: http://auschwitz.org/muzeum/aktualnosci/21-marsz-zywych, 1383.html.

26. Marsz Żywych. Deklaracja pamięci ministrów edukacji. (2017). Pobrano z: http://auschwitz.org/muzeum/aktualnosci/26-marsz-zywych-deklaracja-pamieci-ministrowedukacji-,1894.html.

27. Marsz Żywych z udziatem Prezydentów Polski i Izraela. (2018). Pobrano z: http://auschwitz.org/muzeum/aktualnosci/27-marsz-zywych-z-udzialem-prezydentow-polskii-izraela,1977.html.

A Memorial for Communism Victims of Estonia is Opened Tomorrow in Maarjamäe. (2018). Pobrano z: https://www.just.ee/en/news/memorial-communism-victims-estonia-opened-tomorrow-maarjamae.

Arbeit macht frei opuśit brame - napis poddany konserwacji. (2006). Pobrano z: http:// auschwitz.org/muzeum/aktualnosci/arbeit-macht-frei-opuscil-brame-napis-poddanykonserwacji,496.html.

Assmann, A. (2007). Konstruktion von Geschichte in Museen. Aus Politik und Zeitgeschichte, 49, 6-13.

Cymer, A. (2019). Krajobraz pamięci. Pobrano z: https://culture.pl/pl/artykul/krajobraz-pamieci.

Gębczyńska-Janowicz, A. (2010). Polskie zatożenia pomnikowe. Rola architektury w tworzeniu miejsc pamięci od potowy XX wieku. Warszawa: Wydawnictwo Neriton.

Home Garden. (2021). Pobrano z: https://www.memoriaal.ee/en/garden/. 
IX Marsz Żywych. (2000). Pobrano z: http://auschwitz.org/muzeum/aktualnosci/ix-marsz-zywych, 242.html.

Kapralski, S. (2012). Naród z popiotów. Pamięć zagtady a tożsamość Romów. Warszawa: Wydawnictwo Naukowe Scholar.

Kącka, K. (2015). Polityka historyczna: kreatorzy, narzędzia, mechanizmy działania - przykład Polski. W: K. Kącka, J. Piechowiak-Lamparska, A. Ratke-Majewska (red.). Narracje pamięci: między polityka a historią (ss. 59-80). Toruń: Wydawnictwo Naukowe UMK.

Kozakiewicz, J. (2017). Konkurs na międzynarodowy pomnik ofiar obozu Birkenau. Miejsce, 3. Pobrano z: http://miejsce.asp.waw.pl/konkurs-na-miedzynarodowy-pomnikofiar-obozu-w-birkenau-2/.

Kranz, T. (2000). Miejsca pamięci czy pamięć miejsc? Rozważania o roli upamiętnienia w przekazie społeczno-historycznym. Przesztość i Pamięć, 1, 57-63.

Kranz, T. (2002). Edukacja historyczna w miejscach pamięci. Lublin: Stowarzyszenie „Dia$\log$ i Współpraca”.

Kula, M. (2002). Nośniki pamięci historycznej. Warszawa: Wydawnictwo DiG.

Leśniakowska, M. (2021). Miejsce pamięci na terenie bytego Hitlerowskiego Obozu Zagłady Żydów, Betżec. Pobrano z: https://www.nck.pl/szkolenia-i-rozwoj/projekty/kongres-kultury/aktualnosci/miejsce-pamieci-na-terenie-bylego-hitlerowskiego-obozuzaglady-zydow-belzec-.

Levy, D., Sznaider, N. (2002). Memory Unbound: The Holocaust and the Formation of Cosmopolitan Memory. European Journal of Social Theory, 5, 87-106.

Memorial for the Estonian Victims of Communism. (2021). Pobrano z: https://miesarch. com/work/3915.

Miejsca-symbole w bytym niemieckim obozie Auschwitz. (2015). Pobrano z: https://dzieje.pl/ aktualnosci/miejsca-symbole-w-bylym-niemieckim-obozie-auschwitz.

Mołdawa, M. (1967). Gross-Rosen. Obóz koncentracyjny na Śląsku. Warszawa: Wydawnictwo Polonia.

Netzwerk der Erinnerung. 10 Jahre Gedenkstättenreferat der Stiftung Topografie des Terrors. (2003). Berlin: Stiftung Topografie des Terrors.

Oryginat napisu „Arbeit Macht Frei” powrócit nad bramę do bytego KL Auschwitz. (2006). Pobrano z: http://auschwitz.org/muzeum/aktualnosci/oryginal-napisu-arbeit-macht-freipowrocil-nad-brame-do-bylego-kl-auschwitz,426.html.

Peter Eisenman über das Denkmal. (2021). Pobrano z: https://www.stiftung-denkmal.de/ denkmaeler/denkmal-fuer-die-ermordeten-juden-europas-mit-ausstellung-im-ortder-information/.

Pomnik i jego symbolika. (2021). Pobrano z: http://www.belzec.eu/pl/page/upamietnienie/183.

Przejście. Jerzy Kalina. (2021). Pobrano z: https://sztukapubliczna.pl/pl/przejscie-jerzy-kalina/czytaj/53.

Roloff-Momin, U. (1994). Erinnern an die Orte des Grauens in Berlin-Brandenburg. W: J. Dittberner, A. von Meer (red.). Gedenkstätten im vereinten Deutschland. 50 Jahre nach der Befreiung der Konzentrationslager (ss. 89-96). Berlin: Edition Hentrich. 
Sacha, M.I. (2013). Buchenwald jako przestrzeń zmiennej komunikacji. W: M. Fabiszak, M. Owsiński (red.). Obóz-muzeum. Trauma we wspótczesnym wystawiennictwie (ss. 171-192). Kraków: Universitas.

Sawicki, P. (2017). 26. Marsz Żywych. Deklaracja pamięci ministrów edukacji. Oś Oświęcim - Ludzie - Historia - Kultura, 109, 3.

Skórzyńska, I. (2007). Inscenizacje pamięci: misteria nieobecności w Lublinie. W: I. Skórzyńska, C. Lavrence, C. Pépin (red.). Inscenizacje pamięci (ss. 83-96). Poznań: Wydawnictwo Poznańskie.

Snyder, T. (2015). Czarna ziemia. Holokaust jako ostrzeżenie. Kraków: Znak Horyzont.

Szafkowska, M. (2021). Pomnik Anonimowego Przechodnia. Pobrano z: https://mnwr.pl/ pomnik-anonimowego-przechodnia/.

Szuchta, R. (2015). 1000 lat historii Żydów polskich. Podróż przez wieki. Warszawa: Muzeum Historii Żydów Polskich Polin.

Tambur, S. (2018). A Memorial to the Victims of Communism Opens in Estonia. Pobrano z: https:/lestonianworld.com/life/memorial-to-the-victims-of-communism-opens-in-estonial.

Wierzbicka, A.M. (2011). Architektura miejsc pamięci jako forma strukturyzująca doświadczenia zbiorowe na przykładzie obiektów świadectwa Holokaustu. Czasopismo Techniczne. Architektura, 108(4-A/2), 446-451.

Wolff-Powęska, A. (2011). Pamięć - brzemię i uwolnienie. Niemcy wobec nazistowskiej przesztości (1945-2010). Poznań: Wydawnictwo Zysk i Spółka.

Wysok, W. (2015). Refleksje na kanwie pytania: po co współczesny człowiek ma przyjeżdżać do takich miejsc jak Treblinka?. W: E. Kopówka (red.). Treblinka. Historia i pamięć (ss. 17-31). Siedlce: Muzeum Regionalne w Siedlcach.

Zaborski, M. (2006). Stan wojenny - symboliczne formy pamięci. W: D. Magier (red.). 13 XII 1981. Wiedza historyczna i świadomość spoteczna po 25 latach od wprowadzenia stanu wojennego (ss. 11-25). Radzyń Podlaski: Instytut Badawczy „Libra”. Lublin: Archiwum Państwowe w Lublinie.

Zaborski, M. (2011). Wspótczesne pomniki i miejsca pamięci w polskiej i niemieckiej kulturze politycznej. Toruń: Wydawnictwo Adam Marszałek.

Zawadka, A.P. (2015). Upamiętnianie Treblinki. W: E. Kopówka (red.). Treblinka. Historia i pamięć (ss. 32-56). Siedlce: Muzeum Regionalne w Siedlcach. 